\title{
Increased serum levels of NMDA receptor antibodies in female patients with bipolar disorder
}

\author{
Bipolar bozukluk tanısı olan kadınlarda artmış serum NMDA reseptör \\ antikoru düzeyleri \\ Deniz Ceylan ${ }^{1}$,Pınar Akan²,Kerim Doyuran ${ }^{3}$,Güneş Can ${ }^{4}$, Ayça Erşen ${ }^{5}$,Emre Mısır ${ }^{6}$, Ayşegül Özerdem ${ }^{7}$ \\ ${ }_{1}^{1}$ Assis. Prof., Izmir University of Economics, Vocational School of Health Services, Elderly Care, Izmir, Turkey -https://orcid.org/0000-0002-1438-8240 \\ 2Prof., ${ }^{3}$ M.D. Dokuz Eylül University, Department of Biochemistry, Izmir, Turkey \\ ${ }^{4}$ M.D., Department of Psychiatry, Mardin State Hospital, Mardin, Turkey \\ ${ }^{5}$ Assoc. Prof., Department of Pathology, Acıbadem Healthcare Group, Istanbul, Turkey \\ 6 M.D., Department of Psychiatry, Yozgat City Hospital, Yozgat, Turkey \\ 7 Prof., Dokuz Eylül University, Department of Psychiatry, Izmir, Turkey.
}

\begin{abstract}
SUMMARY
Objective: Glutamatergic/GABAergic imbalance due to autoimmune antibodies targeting $\mathrm{N}$-methyl-D-aspartate receptors (NMDA-R) is considered to be one of the shared pathways between bipolar disorder (BD) and autoimmune diseases. Evidence shows female vulnerability to autoimmune disorders, and suggests a sex-specific approach in autoimmunity research in BD. We aimed to assess serum concentrations of NMDA-R antibodies and density of NMDA and GABA receptors on platelets in euthymic patients with $B D$ in comparison to healthy individuals; and to determine the impact of sex on serum concentrations of NMDA-R antibodies and the density of NMDA and GABA receptors on platelets. Method: NMDA antibody IgG were detected in serum samples of 27 DSM IV euthymic patients with bipolar disorder (16 females, 11 males) and 33 healthy individuals (17 females, 16 males), using ELISA method. The densities of NMDA and GABA receptors on platelets were investigated using immunocytochemical methods. Results: Patients with BD presented higher serum levels of NMDA-R antibodies in comparison to healthy individuals $(p<0.001)$. The densities of NMDA and GABA receptor on platelets were similar in both groups. The NMDA-R antibody levels were influenced by both diagnosis and $\operatorname{sex}(F=5.813, d f=1, p=0.020)$. Tserum lithium levels showed a significant linear association with the serum NMDA-R antibody levels even adjusting for age, sex, body mass index $(\mathrm{F}=-56.26, \mathrm{t}=-2.52, \mathrm{p}=0.015, \mathrm{Cl}$ : $-101.12 /-11.40$ ). Discussion: Our findings support a potential role of NMDA-R antibodies in the underlying pathophysiology of $\mathrm{BD}$, particularly for females.
\end{abstract}

Key Words: Bipolar disorder, NMDA, autoimmunity, anti-NMDA antibody, platelet, GABA, female sex

(Turkish J Clinical Psychiatry 2019;22:125-138)

DOI: $10.5505 / \mathrm{kpd} .2018 .54154$
ÖZET

Amaç: N-metil-D-aspartat reseptörlerini (NMDA-R) hedef alan antikorlar nedeniyle glutamaterjik ve gamma amino butirik asit (GABAerjik) dengenin bozulmasının bipolar bozukluk ile otoimmün hastalık arasındaki ortak yolaklardan biri olabileceği düşünülmektedir. Kanıtlar, kadınların otoimmün hastalıklara duyarlı olduğunu göstermekte ve otoimmünite araştırmalarında biyolojik cinsiyete özgü bir yaklaşımı desteklemektedir. Bu araştırma, bipolar bozukluğu olan ötimik hastaların serumlarında NMDA-R antikorlarının konsantrasyonlarını ve trombositlerinin yüzeylerindeki NMDA ve GABA reseptörlerinin yoğunluğunu sağlıklı kontrollerinkilerle karşılaştırmalı olarak değerlendirmeyi; ve cinsiyetin NMDA-R antikorlarının serum konsantrasyonlarına ve trombositler üzerindeki NMDA ve GABA reseptörlerinin yoğunluğuna etkisini saptamayı amaçlamaktadır. Yöntem: DSM IV'e göre bipolar bozukluk tanısı olan 27 ötimik hastanın (16 kadın, 11 erkek) ve 33 sağlıklı bireyin (17 kadın, 16 erkek) serum örneklerinde NMDA antikor IgG düzeyleri ELizA yöntemi ile saptandı. NMDA ve GABA reseptörlerinin trombositler üzerindeki yoğunluğu immünositokimyasal yöntemler kullanılarak araştırıldı. Bulgular: Bipolar bozukluğu olan hastaların serumlarında sağlıklı bireylerinkilere göre daha yüksek NMDA-R antikoru düzeyleri saptandı $(p<0.001)$. Her iki grupta NMDA ve GABA reseptörünün trombosit yüzeylerindeki yoğunlukları benzerdi. NMDA-R antikor düzeylerinin hastalık varlığı ve cinsiyetin tarafından etkilendiği saptandı $(F=5.813$, $d f=1, p=0.020$ ). Serum Lityum düzeyleri, yaş, cinsiyet, beden kitle indeksi ve sigara kullanımı açısından düzeltilmiş olarak, serum NMDA reseptör antikorları ile anlamlı negatif lineer ilişki göstermiştir $(F=-56.26, t=-$ 2.52, $\mathrm{p}=0.015, \mathrm{Cl}:-101.12 /-11.40)$. Sonuç: Bulgularımı, bipolar bozukluğun patofizyolojisinde, özellikle kadın hastalarda, NMDA-R antikorlarının olası rolünü işaret etmektedir.

Anahtar Sözcükler: bipolar bozukluk, NMDA, otoimmünite NMDA antikoru, GABA, kadın cinsiyet 


\section{INTRODUCTION}

Bipolar Disorder (BD) is a chronic, severe mental illness, which has been repeatedly associated with high comorbidity with various types of autoimmune diseases (1-6). Certain types of autoimmune diseases, such as thyroiditis (7), systemic lupus erythematosus (8-10) and multiple sclerosis $(11,12)$, share some similar symptoms (i.e. affective symptoms, cognitive dysfunction) with mood episodes of BD. Even though several shared pathophysiological pathways (e.g. glutamatergic insults, immune dysfunction) between $\mathrm{BD}$ and autoimmune diseases have been implicated in the increased comorbidity with such diseases in patients with $\mathrm{BD}$ (13-15), the underlying nature of the relationship between $\mathrm{BD}$ and autoimmune comorbidities has not yet been clearly defined.

Alterations in both of glutamate and Gamma amino butiric acid (GABA) mechanisms, one of the prominent disturbances related to neurobiology of $\mathrm{BD}$, may have possible associations with autoimmunity in BD (16-19). Glutamate is the main excitatory, whereas GABA is the main inhibitory neurotransmitter in the central nervous system (17). Several studies suggest significant abnormalities in concentrations and functions of the glutamatergic and GABAergic receptors in $\mathrm{BD}$ (22-27). Despite growing evidence on the importance of glutamatergic / GABAergic dysregulation and immune dysfunctions in the neurobiology of BD (25), there is limited data on the role of the antibodies targeting glutamatergic system in the pathophysiology of BD.

Autoimmune antibodies against NMDA receptors can cause reversible and selective decreases in NMDA receptors' surface density by a mechanism of cross-linking and internalization, that correlates with the levels of NMDA receptor antibodies (2832). Previous evidence demonstrated increased NMDA-R antibodies in serum or cerebrospinal fluid samples of patients with a variety of disorders, such as encephalitis, epilepsy, systemic lupus erythematosus, as well as psychotic and affective disorders (33-39). Furthermore, a meta-analysis study reported that patients with a range of psychiatric conditions, including $\mathrm{BD}$ had a three times greater likelihood to have increased serum levels of NMDA-R antibodies in comparison to healthy individuals (40). This evidence may indicate the possible role of the NMDA-R antibodies in the glutamatergic / GABAergic disturbances, as well as abnormal glutamatergic / GABAergic receptor functionality in $\mathrm{BD}$ (35).

Epidemiological data shows that several autoimmune disorders, such as systemic lupus erythematosus, Sjögren's syndrome and thyroiditis, are more prevalent in females (41-43). Notably, NMDA-R encephalitis, an autoimmune disease in which autoimmune antibodies attack NMDA receptors at central neuronal synapses, is one of the diseases showing most prominent degrees of sex bias, and predominantly seen in young females $(30,31)$. It is well known that several sex differences also exist in the presentation and clinical course of $\mathrm{BD}$; and females with $\mathrm{BD}$ are more prone to develop depressive and mixed episodes, BD type II, seasonal variations and rapid cycling BD (4448 ), as well as comorbid obesity (49), autoimmune thyroid diseases (50-53) and migraine (54,55). Recent evidence show several sex specific differences in several parameters, including oxidative stress $(56)$, cognition $(57,58)$ and brain structures between sexes in $\mathrm{BD}(59,60)$. Further investigation is needed to understand the possible associations between sex specific autoimmune mechanisms and glutamatergic/GABAergic dysfunction in BD (44).

The primary objective of this study was to assess concentrations of NMDA-R antibodies in serum samples, and densities of NMDA and GABA receptors on surface of platelets in patients with $\mathrm{BD}$ in comparison to healthy individuals. A secondary aim was to highlight the potential impact of sex on serum concentrations of NMDA-R antibodies, densities of NMDA and GABA receptors on the surface of platelets in patients and controls.

\section{METHOD}

\section{Participants}

Patients with BD type I who had been euthymic for at least six months $(n=35)$ were recruited from the Mood Disorder Unit of the Dokuz Eylul 
University. Patients who had been euthymic for at least six months were selected in order to override potential confounding effect of an acute episode or possible residual effects of a previous episode on the findings.

Healthy individuals $(\mathrm{HI})(\mathrm{n}=33)$ with no known medical problems, no family history of major psychiatric or neurological disorders, mental retardation, cancer, cardiovascular disease or diabetes mellitus, who volunteered for the study through announcements, were recruited. As semi-structured interview for DSM-5 has not been available yet, the Structural Clinical Interview for DSM-IV interview was used to confirm psychiatric conditions of the healthy individuals and patients (62). Symptomatic severity was assessed using Young Mania Rating Scale (YMRS) (63), Hamilton Depression Scale-17 (HAMD-17) (64), Clinical Global Impression (CGI) (65) and Global Assessment of Functionality (GAF) (66) scales.

The exclusion criteria for the patients were as follows: having any comorbid axis I psychiatric diagnosis, acute infection, having any significant problem in routine blood and urine tests, neurological disorders, history of head trauma, chronic medical condition (e.g.,hypertension, diabetes mellitus), substance use (excluding tobacco), neurodegenerative diseases, epilepsy or previous brain surgery, auditory or visual impairment, and being pregnant or breastfeeding. According to these criteria, two patients were excluded due to diabetes mellitus comorbidity, one patient due to ankylosing spondylitis comorbidity, two patients were excluded because of depressive symptoms (HAMD-17 score $>7$ ), and one due to manic symptoms (YMRS $>7$ ). An additional two patients were excluded due to hemolysis, which made it impossible to study their samples. 27 patients with BD and 33 healthy individuals were included in the study. The study was approved by the local ethics committee of the Dokuz Eylul University. All participants provided written informed consent.

\section{Collection and preparation of the blood samples}

An experienced physician obtained the blood samples between 10-12 am after an overnight fast by patients.

Serum samples were kept at $-80^{\circ} \mathrm{C}$ until ELISA tests for NMDA antibody levels. Platelet rich plasma (PRP) samples were obtained from $10 \mathrm{ml}$ blood samples in citrate-tubes by centrifuging 10 minutes at 200g. After adding DMSO (10\%), the PRP samples were kept at $-80 \quad \mathrm{C}$ until further analyses of NMDA and GABA receptors on platelets.

\section{ELISA tests}

Human NMDA-R antibodies ( $\operatorname{IgG}$ ) in serum were investigated by the quantitative double antigen sandwich enzyme linked immunosorbent assay (Human NMDA antibody (IgG) ELISA kit, Sunredbio, Shanghai, catalogue no: 201-12-2139) according to manufacturing instructions. Briefly, human NMDA-R antibodies ( $\mathrm{IgG}$ ) were antigen labelled with biotin and combined with streptavidin- HRP. Labeled antigens formed immune complex after incubation with NMDA-R antibodies (IgG) in serum samples. Following a wash period to remove any unbound reagent, a substrate solution was added to the wells and color developed in proportion to the amount of human NMDA antibody $(\operatorname{IgG})$ bound. The color development was stopped and the intensity of the color was measured at $450 \mathrm{~nm}$ with-in 15 minutes.

The assays were performed in duplicate and different plate areas were identified in 96-well plates and tested blind to detect any variations. The sensitivity of the kit was $1,582 \mathrm{pg} / \mathrm{mL}$ and the assay limits of the method were between 2 and $600 \mathrm{pg} / \mathrm{mL}$. Inter-assay coefficient variation (CV) was $\sim 10 \%$. A five point concentration calibration curve, ranging from 20 to $320 \mathrm{pg} / \mathrm{mL}$, was used for quantification of human NMDA-R antibodies ( $\mathrm{IgG}$ ). The absorbance of the samples lower than the absorbance of the lowest calibrator was interpreted as $\leq 20 \mathrm{pg} / \mathrm{mL}$ to obtain analytical safety.

\section{Immunocytochemical process}

The PRP samples from 45 of the participants ( 28 patients with $\mathrm{BD}, 17 \mathrm{HI}$ ) were selected after optimization processes for immunocytochemical 
assessment (15 participants did not provide PRP samples), and analyzed using immunocytochemical methods to investigate the profiles of NMDA and GABA receptors. Anti-NMDAR2A (clone ab78483, 1:100, Abcam) and Anti-GABA antibodies (clone ab86186, 1:100, Abcam) were applied on cytospin preparations of PRP samples which were fixed in $95 \%$ alcohol before immunostaining. Immunohistochemistry conditions were optimized for each individual antibody using manufacturers' recommendations. The immunostaining density was scored as 0 : negative, 1 : low density, 2: moderate density, 3: high density.

\section{Statistical analyses}

We identified and quantified the levels of NMDA antibody in serum samples, density of NMDA and GABA receptor on platelets samples from patients and healthy individuals.

Skewness and kurtosis calculations were used to test normality for continuous variables. NMDA antibody levels were log transformed to provide normal distribution. Group differences were evaluated with independent samples t-test. Chi-Square test was used to examine categorical data. The impact of sex, smoking and BD diagnosis on the NMDA-R antibody levels was determined using three-way univariate analysis which included diagnosis, sex and smoking status as fixed factors and age as a covariate.

Pearson correlation tests were applied to explore the correlations between clinical variables and dependent variables. Linear regression analysis were applied to confirm the impacts of clinical variables on dependent variables. The significantly correlated variables and possible confounders (i.e. age, sex, body mass index and smoking status) were included in linear regression analyses. The IBM SPSS Statistics 25.0 (Chicago IL, USA) for Windows was used for data analysis. A p-value < 0.05 was assumed to correspond to statistically significant difference between means.

\section{RESULTS}

Sociodemographic and clinical characteristics of the $\mathrm{BD}$ patients and healthy individuals are described in Table 1. There were no significant differences between the BD patients and healthy individuals with respect to variables of sex, smoking status and body mass index. The patient group $(40.74 \pm 8.24)$ was significantly older than the healthy group $(34.97 \pm 8.29)(\mathrm{F}=0.008, \mathrm{df}=58, \mathrm{p}=$ 0.009).

Patient group was consisted of 16 females and 11 males with BD type I. The mean duration of illness was $14.74 \pm 6.67$ years, and the duration of current euthymia was $35.35 \pm 36.17$ weeks. All patients were on psychotropic medications; four patients were receiving a single medication: one, an antidepressant, two, valproate, and one, lithium carbo-nate. Three patients were on lithium carbonate and valproate combination, five on two mood-stabilizers in combination with a second generation-antipsychotic, eleven on a mood stabilizer in combination with a second generation antipsychotic, and five on a mood-stabilizer in combination with a second generation-antipsychotic and an antidepressant. The mean duration of mood-stabilizer use was $108.26 \pm 64.28$ weeks, and the mean duration of antipsychotic use was $68.22 \pm 63.23$ weeks.

\section{The levels of NMDA-R antibodies}

Patients with BD had significantly higher serum NMDA antibody levels $(39.24 \pm 20.11 \mathrm{pg} / \mathrm{mL})$ in comparison to healthy individuals $(23.96 \pm 11.73$ $\mathrm{pg} / \mathrm{mL})(\mathrm{t}=4.363, \mathrm{df}=58, \mathrm{p}<0.001) \quad($ Fig.1). The number of subjects with NMDA antibody levels below $20 \mathrm{pg} / \mathrm{mL}(\mathrm{n}=35 ; 58.3 \%)$ was significantly lower in patients with BD $(n=7 ; 25.9 \%)$ compared to that of healthy controls $(\mathrm{n}=28 ; 84.4 \%)$ ( $\mathrm{p}$ $<0.001)$.

Further comparisons showed that there was no significant difference between smokers and nonsmokers with respect to serum NMDA antibody levels $(\mathrm{p}=0.458)$. Females with BD (46.06 \pm 22.01 $\mathrm{pg} / \mathrm{mL}$ ) had significantly higher serum levels of NMDA antibody than males with BD (29.33 \pm $11.94 \mathrm{pg} / \mathrm{mL})(\mathrm{t}=2.478, \mathrm{df}=25, \mathrm{p}=0.020)$, whereas 
Table 1. Demographic and clinical characteristics of the participants

\begin{tabular}{|c|c|c|c|}
\hline & $\mathrm{BD}(\mathrm{n}=27)$ & $\mathrm{HI}(\mathrm{n}=33)$ & $p$-value \\
\hline Gender (number of females, $\%)^{\mathrm{a}}$ & $\mathrm{n}=16,59.3 \%$ & $\mathrm{n}=17,51.5 \%$ & $\chi^{2}=0.360, \mathrm{df}=1, \mathrm{p}=0.549$ \\
\hline $\mathrm{Age}^{\mathrm{b}}$ & $40.74-8.24$ & $34.97-8.29$ & $\mathrm{~F}=0.008, \mathrm{df}=58, \mathrm{p}=0.009$ \\
\hline Smoking (number of smokers, $\%)^{\mathrm{b}}$ & $\mathrm{n}=12,44.4 \%$ & $\mathrm{n}=7,24.1 \%$ & $\chi^{2}=2.572, \mathrm{df}=1, \mathrm{p}=0.109$ \\
\hline Body Mass Index ${ }^{\mathrm{b}}$ & $28.37-4.78$ & $26.92-3.81$ & $\mathrm{~F}=1.962, \mathrm{df}=45, \mathrm{p}=0.262$ \\
\hline Age of illness onset & $25.70-8.44$ & & \\
\hline Duration of illness (years) & $14.74-6.67$ & & \\
\hline $\mathrm{N}$ of hospitalizations & $2.33-1.40$ & & \\
\hline Duration of current euthymia (months) & $35.35-36.17$ & & \\
\hline $\mathrm{N}$ of previous episodes & $6.04-4.36$ & & \\
\hline $\mathrm{N}$ of manic episodes & $2.26-1.46$ & & \\
\hline $\mathrm{N}$ of hypomanic episodes & $1.70-3.99$ & & \\
\hline $\mathrm{N}$ of depressive episodes & $1.67-1.75$ & & \\
\hline $\mathrm{N}$ of mixed episodes & $0.52-0.82$ & & \\
\hline Clinical Global Impressions score & $1.85-0.46$ & & \\
\hline Global Assessment of Functionality score & $81.67-8.09$ & & \\
\hline Hamilton Depression Scale score & $2.89-1.89$ & & \\
\hline Young Mani Rating Scale score & $0.89-1.58$ & & \\
\hline
\end{tabular}

$a$ : Chi-Square; $b$ : independent samples t test.

\begin{tabular}{|c|c|c|c|c|}
\hline & & NMDA-R & Plattelet & Plattelet \\
\hline & & Antibody levels & NMDA-R intensity & GABA-R intensity \\
\hline \multirow[t]{3}{*}{ Age } & $\mathrm{r}$ & $0.270^{*}$ & 0.192 & -0.177 \\
\hline & $\mathrm{p}$ & 0.037 & 0.223 & 0.263 \\
\hline & $\mathrm{n}$ & 60 & 42 & 42 \\
\hline \multirow[t]{3}{*}{ Body mass index $\left(\mathrm{kg} / \mathrm{m}^{2}\right)$} & $\mathrm{r}$ & 0.029 & -0.039 & 0.210 \\
\hline & $\mathrm{p}$ & 0.845 & 0.819 & 0.213 \\
\hline & $\mathrm{n}$ & 47 & 37 & 37 \\
\hline \multirow[t]{3}{*}{ Number of manic episodes } & $\mathrm{r}$ & 0.148 & $-0.610^{* *}$ & -0.347 \\
\hline & $\mathrm{p}$ & 0.463 & 0.001 & 0.089 \\
\hline & $\mathrm{n}$ & 27 & 25 & 25 \\
\hline \multirow[t]{3}{*}{ Number of depressive ep sodes } & $\mathrm{r}$ & -0.081 & -0.168 & 0.079 \\
\hline & $\mathrm{p}$ & 0.690 & 0.423 & 0.706 \\
\hline & $\mathrm{n}$ & 27 & 25 & 25 \\
\hline \multirow[t]{3}{*}{ Duration of illness (years) } & $\mathrm{r}$ & -0.190 & 0.074 & -0.221 \\
\hline & $\mathrm{p}$ & 0.343 & 0.724 & 0.289 \\
\hline & $\mathrm{n}$ & 27 & 25 & 25 \\
\hline \multirow[t]{3}{*}{ Duration of euthymia (months) } & $\mathrm{r}$ & 0.032 & 0.162 & 0.090 \\
\hline & $\mathrm{p}$ & 0.876 & 0.451 & 0.677 \\
\hline & $\mathrm{n}$ & 26 & 24 & 24 \\
\hline \multirow{3}{*}{$\begin{array}{l}\text { Global Assessment of Functioning } \\
\text { score }\end{array}$} & $\mathrm{r}$ & 0.247 & $.412^{*}$ & 0.247 \\
\hline & $\mathrm{p}$ & 0.215 & 0.041 & 0.234 \\
\hline & $\mathrm{n}$ & 27 & 25 & 25 \\
\hline \multirow{3}{*}{$\begin{array}{l}\text { Hamilton Depression Rating Scale } \\
\text { score }\end{array}$} & $\mathrm{r}$ & -0.306 & -0.233 & -0.277 \\
\hline & $\mathrm{p}$ & 0.120 & 0.263 & 0.181 \\
\hline & $\mathrm{n}$ & 27 & 25 & 25 \\
\hline \multirow[t]{3}{*}{ Young Mania Rating Scale score } & $\mathrm{r}$ & -0.112 & $-0.422^{*}$ & 0.144 \\
\hline & $\mathrm{p}$ & 0.577 & 0.036 & 0.493 \\
\hline & $\mathrm{n}$ & 27 & 25 & 25 \\
\hline \multirow[t]{3}{*}{ Serum Lithium level $(\mathrm{mmol} / \mathrm{l})$} & $\mathrm{r}$ & $-0.593^{*}$ & -0.049 & -0.257 \\
\hline & $\mathrm{p}$ & 0.020 & 0.875 & 0.396 \\
\hline & $\mathrm{n}$ & 15 & 13 & 13 \\
\hline \multirow[t]{2}{*}{ Serum Valproate level (ug/ml) } & $\mathrm{r}$ & -0.025 & 0.551 & 0.124 \\
\hline & $\mathrm{p}$ & 0.936 & 0.063 & 0.701 \\
\hline
\end{tabular}


A

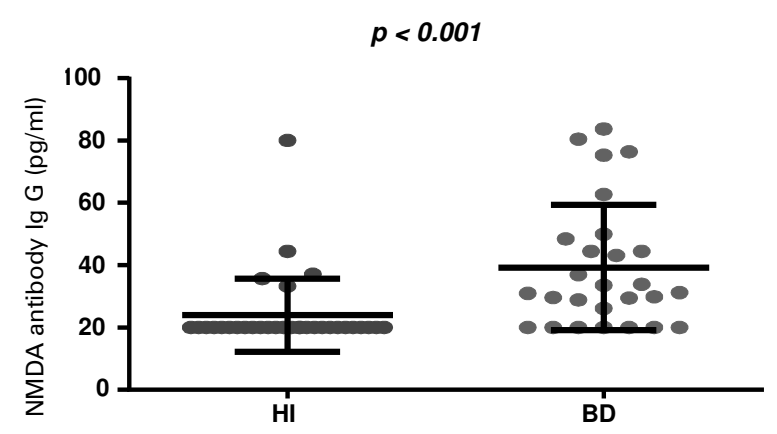

$\mathbf{B}$

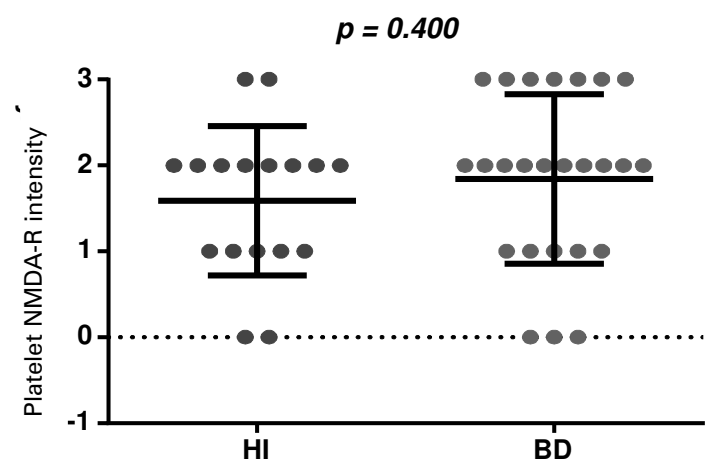

C

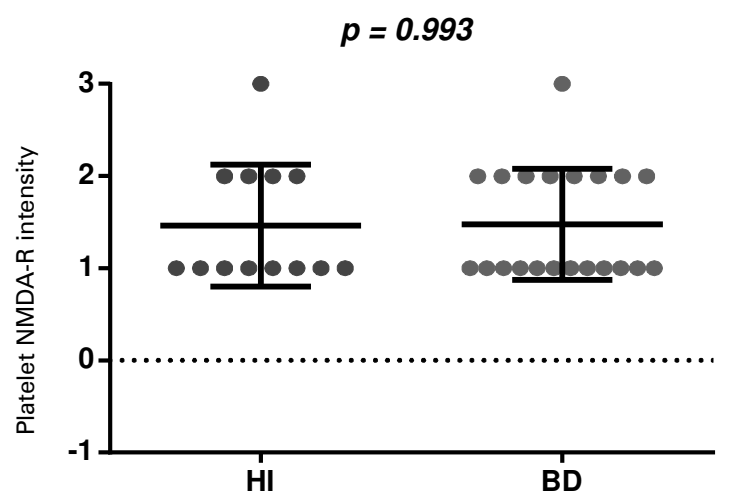

Figure 1: A. Patients with BD had significantly higher serum NMDA-R antibody levels in comparison to healthy individuals $(\mathrm{t}=4.363$, $\mathrm{df}=58, \mathrm{p}<0.001)$. B. No significant difference between patients with BD and healthy individuals with respect to density of NMDA receptors on platelets. C. No significant difference between patients with BD and healthy individuals with respect to density of GABA receptors platelets $(\mathrm{p}=0.400 ; \mathrm{p}=0.993)$. 
there was no significant difference between healthy females and males with respect to NMDA-R antibodies $(p=0.388)$. Additionally, while female patients with $\mathrm{BD}$ had significantly higher levels of NMDA-R antibodies $(46.06 \pm 22.01 \mathrm{pg} / \mathrm{mL}) \mathrm{com}$ pared to healthy females $(22.22 \pm 6.57 \mathrm{pg} / \mathrm{mL})(\mathrm{t}=$ 5.145 , df $=21,365, p<0.001)$, there was no significant difference between male patients with BD $(29.33 \pm 11.94)$ and heathy males $(25.81 \pm 11.73$ $\mathrm{pg} / \mathrm{mL}$ ) with respect to serum NMDA antibody levels $(\mathrm{p}=0.532)$ (Fig. 2).

Serum NMDA-R antibody levels showed a weak correlation with age $(\mathrm{r}=0.270, \mathrm{p}=0.037)$, and a moderately negative correlation with serum lithium levels of patients receiving lithium $(\mathrm{r}=-0.593, \mathrm{n}=$ $15, p=0.020)$. A significant linear regression analyses that included age, sex, body mass index, smoking status and serum Lithium levels as independent factors, revealed the significant effects of serum lithium levels on serum NMDA-R antibody levels $(\mathrm{F}=-56.26, \mathrm{t}=-2.52, \mathrm{p}=0.015, \mathrm{CI}:-101.12 /-$ 11.40). A three-way univariate analysis of covari- ance revealed a significant impact of diagnosis and sex on NMDA-R antibody levels even after adjusting for age and smoking status $(\mathrm{F}=5.813, \mathrm{df}=1, \mathrm{p}$ $=0.020$ ).

\section{Density of NMDA and GABA receptors on the sur- face of platelets}

There were no significant differences between patients with $\mathrm{BD}$ and healthy individuals with respect to NMDA $(p=0.400)$ and GABA receptor on platelets $(p=0.993)$ (Fig. 1). There were no significant differences between female patients with BD and healthy females with respect to NMDA and GABA receptor profiles on platelets $(\mathrm{p}=$ $0.434 ; p=0.466$, respectively), nor between male patients with $\mathrm{BD}$ and healthy males with respect to NMDA and GABA receptor profiles on platelets $(p=0.401 ; p=0.881$, respectively).

The density of NMDA receptors on platelets were positively correlated with density of GABA receptors on platelets $(r=0.384, p=0.012)$. The density

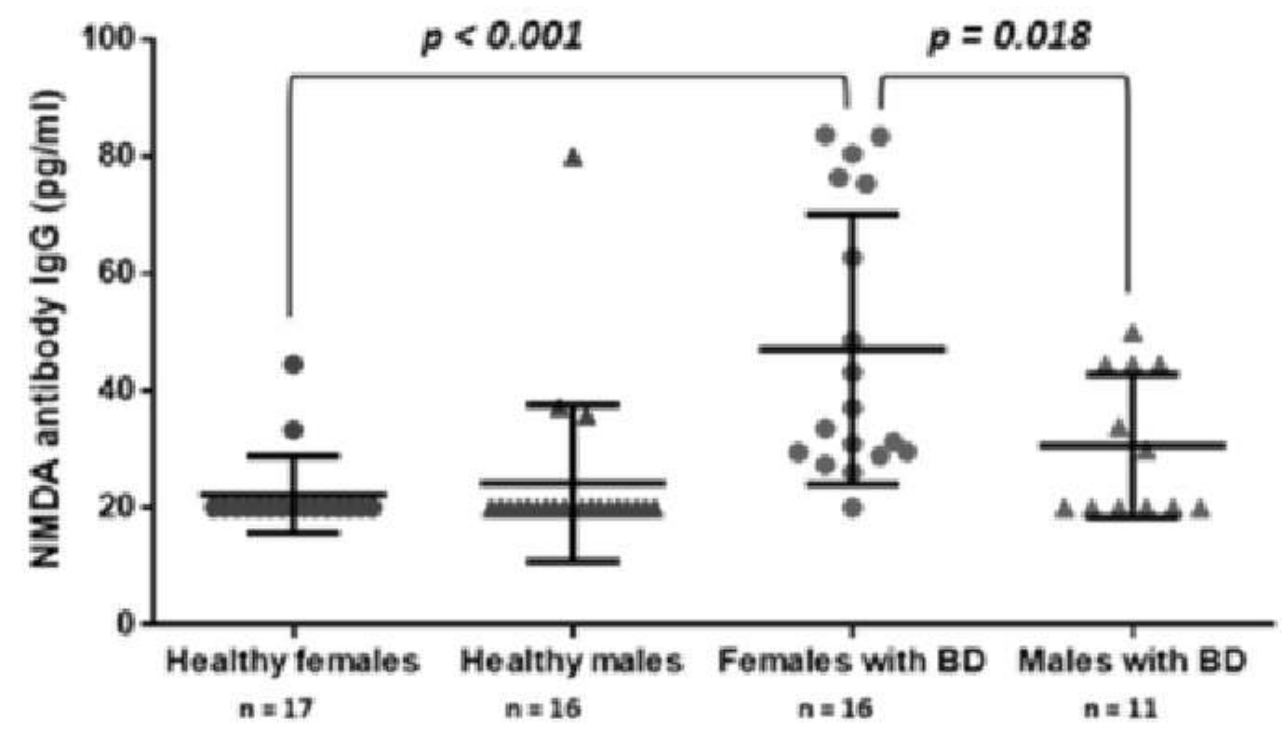

Figure 2: Females with BD $(46.06 \pm 22.01 \mathrm{pg} / \mathrm{mL})$ had significantly higher serum levels of NMDA antibody than males with $\mathrm{BD}(29.33 \pm 11.94 \mathrm{pg} / \mathrm{mL})(\mathrm{t}=2.478, \mathrm{df}=25, \mathrm{p}=0.020)$, whereas there was no significant difference between healthy females and males with respect to NMDA-R antibodies $(p=0.388)$. Additionally, while female patients with BD had signi?cantly higher levels of NMDA-R antibodies (46.06 $\pm 22.01 \mathrm{pg} / \mathrm{mL})$ compared to healthy females $(22.22 \pm 6.57 \mathrm{pg} / \mathrm{mL})(\mathrm{t}=5.145, \mathrm{df}=21,365, \mathrm{p}<0.001)$, there was no significant difference between male patients with BD $(29.33 \pm 11.94)$ and heathy males $(25.81$ $\pm 11.73 \mathrm{pg} / \mathrm{mL})$ with respect to serum NMDA antibody levels $(\mathrm{p}=0.532)$. 
of NMDA receptors on platelets was negatively correlated with total number of manic episodes $(\mathrm{r}=-0.610, \mathrm{p}=0.001)$ and YMRS score $(-0.422$, $\mathrm{p}=0.036)$. A significant linear regression analyses that included age, sex, smoking status, total number of manic episodes and YMRS scores as independent factors, confirmed the significant effects of total number of manic episodes $(\mathrm{F}=-0.435, \mathrm{t}=$ 4.87, p<0.001, CI: $-0.614 /-0.256)$ and YMRS scores $(\mathrm{F}=-0.238, \mathrm{t}=-2.745, \mathrm{p}<0.008, \mathrm{CI}:-0.412 /-0.064)$ on the densities of NMDA receptors on platelets.

\section{DISCUSSION}

To the best of our knowledge, this is the first study addressing NMDA-R antibodies and density of GABA receptors on the surface of platelets in euthymic patients with $\mathrm{BD}$ in comparison to healthy individuals. Our findings show increased levels of NMDA-R IgG antibodies in euthymic patients with $\mathrm{BD}$ compared to healthy individuals. The increase is mainly driven by female participants. However, we detected no significant change in the platelet NMDA or GABA receptor density in $\mathrm{BD}$ patients compared to controls.

\section{NMDA-R antibodies}

Possible associations between autoimmune mechanisms and the underlying neurobiology of $\mathrm{BD}$ are suggested by three types of studies: Epidemiologic studies reporting that autoimmune diseases are more prevalent in BD $(4,61,67)$; studies reporting that patients with autoimmune diseases are more prone to develop BD $(4,68)$; and several case-control studies reporting higher prevalence of several antibodies in BD (69-71). More recently, increased NMDA-R antibodies have been shown in BD $(35,36,40)$ suggesting that the well-documented disturbances in NMDA functioning in $\mathrm{BD}$ may be caused by increased levels of circulating NMDA-R antibodies. In accordance with the previous evidence, we found higher levels of NMDA-R antibodies in euthymic patients with BD compared to healthy individuals $(36,38-40)$. As our BD patient group was significantly older than the control group, we adjusted the results for age following previous literature showing an effect of age on antibody levels $(72,73)$. However, even after adjust- ments with age, sex and smoking status, the group of patients with BD had higher levels of NMDA-R IgG antibodies than the group of healthy individuals.

The previous literature focusing on the serum NMDA-R antibodies in psychiatric disorders is predominantly based on qualitative assessment of NMDA-R antibody sero-positivity ratios. These studies reported increased prevalence of serum NMDA-R antibody positivity in 3-10\% of psychotic patients $(38,74)$. However, these studies have substantial discrepancies, including study population selection and types of immunoglobulins or NMDA receptor subunits or assays (i.e. cell based assay or ELISA) (40). Therefore, caution should be taken while comparing our results with those of previous studies. Our study population focused exclusively on patients with $\mathrm{BD}$, whereas previous studies used mixed groups of BD and psychosis patients $(36,39)$.

Of note, we detected serum levels (i.e. titers) of NMDA-R antibodies quantitatively using a commercial ELISA assay. Majority of the previous studies evaluating anti-NMDA-R antibodies did not use ELISA. Instead, they used other methods due to concerns regarding the tridimensional structure of the related antigen (34). Only one previous study provided quantitative data on serum titers of NMDA-R IgG antibodies, and showed significantly increased serum levels of NMDA-NR2 antibodies in manic patients (36). We focused exclusively on IgG subtype of NMDA-R antibodies in line with the previous data, which showed increased levels of IgG antibodies alone in patients with psychosis compared to controls, in the absence of any change in the levels of any subtype (IgG, IgM, IgA) of NMDAR antibodies (33).

It is important to note that our study population consisted of euthymic patients with BD who had experienced no mood episodes for at least 6 months. Dickerson et al. (2012) showed significantly increased serum levels of NMDA-NR2 antibodies only in manic patients with BD or schizoaffective disorder, in comparison to healthy individuals (36). Furthermore, manic patients' serum NMDANR2 antibody levels decreased at the six-month 
follow-up; which implies an association between antibody levels and the manic state. Previous data from case reports (75-78) and case-control studies $(36,38,79)$ suggest a possible relationship with NMDA-R antibody seropositivity and manic or depressive mood episodes. Despite focusing exclusively on euthymic patients, our results revealed significantly higher NMDA-R antibodies in patients with BD. This finding suggests that NMDA autoimmunity persists in euthymic phases of BD. Further data are needed to highlight the effects of different states of the illness (i.e., euthymia vs. being in episode) on NMDA-R antibody levels. On the other hand, our results revealed that NMDA receptor density on platelets was negatively correlated with both total number of previous manic episodes and also current manic symptom severity. These are in line with previous reports, implying a significant effect of mania on glutamatergic system.

Our further analysis (i.e. three-way univariate analysis of covariance) revealed that the increase in the levels of NMDA-R antibodies was driven by female patients with BD. The female vulnerability to autoimmunity is well documented (37-39). Significantly higher NMDA-R antibody levels in females with $\mathrm{BD}$ compared to healthy females, in the absence of any corresponding difference for males may suggest a female specific vulnerability to NMDA-R autoimmunity in BD. Despite similar ratios of sexes in $\mathrm{BD}$ type I, emerging evidence suggest sex differences in the presentation and clinical course of BD (45). Considering increased comorbidity with certain diseases in females (49-55), and previous data showing significant sex differences in $\mathrm{BD}$, with respect to oxidative stress (56), cognitive decline $(57,58)$ and brain structures $(59,60)$; our finding of sex specific increase of serum NMDA-R antibodies may indicate the importance of a sex specific approach when investigating NMDA-R autoimmunity in BD.

Our data showed significant negative correlations between NMDA-R antibodies and serum lithium levels. Furthermore, a linear regression analysis confirmed the significant linear association between NMDA-R antibodies and serum lithium levels, even after adjustment for possible confounders including age, sex, body mass index and smoking. Although lithium, the gold standard medication of $\mathrm{BD}$, is considered to have immune modulatory effects, its mode of action is not fully understood (80). Several lines of clinical evidence suggest that lithium has neuroprotective effects via neurotrophic, antioxidant, anti-inflammatory mechanisms $(81,82)$. Evidence shows that lithium protects neurons from glutamatergic excitotoxicity $(83,84)$ or modulates glutamate receptors $(85)$. Conforming the growing range of evidence showing neuroprotective effects of lithium against immune and glutamatergic insults, our preliminary data deserve further investigation.

\section{NMDA and GABA receptors on surface of platelets}

This is, as far as we know, the first study investigating NMDA and GABA receptors on surface of platelets in patients with BD. We measured density of NMDA and GABA receptors on platelets in plasma enriched plasma samples using immunocytochemical methods. As platelets express glutamatergic and GABAergic receptors that are analogous to those in the brain, platelets may be considered as a significant and easily accessible alternative to neuronal cells in the study of the GABA/Glutamate system (86-90). Only a limited number of studies demonstrated changes in glutamate receptor functions in platelets of patients with psychiatric disorders including schizophrenia (91, 92) and major depression (93). While one study reported alterations in glutamate uptake in platelets of patients with BD (94), and another showed GABA receptors on platelets (95), no study specifically investigated GABA receptors on platelets in psychiatric disorders.

Our results show no change in density of NMDA and GABA receptors on platelets in patients with $\mathrm{BD}$ in comparison to healthy individuals, and no correlations with density of NMDA on surface of platelets and patients' antibody titers. However, a possible relationship between surface NMDA receptor expressions and manic symptoms is implicated by negative linear associations between density of NMDA receptors, Young Mania Rating Scale scores, which may implicate subclinical or residual manic symptoms in the euthymia group, and number of previous manic episodes. 
Supporting this point of view are previous animal studies showing significant decreases in surface expression of NMDA receptor subunits in hippocampus (96-98). Future longitudinal studies may highlight impacts of manic episodes on platelet NMDA receptor expressions.

\section{Strengths and limitations}

The two main strengths of this study were, first, the combined investigation of both NMDA-R antibodies and density of NMDA and GABA receptors on platelet surface; and second, the study was carried out in a homogenous patient population based on stringent inclusion criteria. Nevertheless, certain limitations of the study should be noted. The small sample size and the inclusion of only medicated patients should be considered while interpreting the results. Small differences of NMDA and GABA receptor density might have become invisible not only due to the small sample size, but also possible protective effects of medications. Many drugs used in the treatment of BD including mood-stabilizers, antipsychotics and antidepressants were shown to have modulating effects on NMDA receptors (99-103) as well as GABA receptors (104-106). Therefore, further studies excluding medicated patients are needed to clarify the effect of illness on the glutamate/GABA systems. Older age in patient sample might be another limitation of the study. However, all results were controlled for age.

Using serum samples and platelets, rather than cerebrospinal fluid and brain tissue, might also have affected our results. Another limitation includes the laboratory techniques we used. Despite being coherent with previous results, our results of the ELISA assessments need further replication using cell-based assays. Moreover, further studies targeting subunits of NMDA receptors such as NR-1, NR-2 are needed. The immunocytochemical technique was used to identify receptor densities on platelet surface, and further studies using quantitative techniques (e.g. flow cytometry) would improve the understanding of platelet receptor functioning in $\mathrm{BD}$.

Finally, as a major limitation of the study, the cross- sectional design does not allow to control our results for the possible confounding effects of individual factors that predispose to autoimmunity including exposure to infectious agents, dietary components, chemicals, toxins or stress. Future follow up studies will raise the understanding in the field.

\section{CONCLUSION}

Our finding of increased levels of NMDA IgG antibodies in euthymic patients with BD support the notion that the autoantibodies targeting NMDA receptors may represent a possible key area for understanding the neurobiology of $\mathrm{BD}$, particularly for females. The negative correlation between the platelet surface density of NMDA receptors and number of the previous manic episodes, as well as current manic symptoms, may reflect the impact of mania on the glutamatergic system. Another implication of our results is that lithium may have a potential protective action against glutamatergic insults. However, further follow up studies with larger sample size are needed to verify these results.

Correspondence address: Assis. Prof. Deniz Ceylan, Izmir University of Economics, Vocational School of Health Services, Elderly Care, Izmir, Turkey denizceylandr@gmail.com 


\section{REFERENCES}

1. Sylvia LG, Shelton RC, Kemp DE, Bernstein EE, Friedman ES, Brody BD, McElroy SL, Singh V, Tohen M, Bowden CL, Ketter TA, Deckersbach T, Thase ME, Reilly-Harrington NA, Nierenberg AA, Rabideau DJ, Kinrys G, Kocsis JH, Bobo WV, Kamali M, McInnis MG, Calabrese JR. Medical burden in bipolar disorder: findings from the Clinical and Health Outcomes Initiative in Comparative Effectiveness for Bipolar Disorder study (Bipolar CHOICE). Bipolar Disord 2015;17:212-23.

2. Perugi G, Quaranta G, Belletti S, Casalini F, Mosti N, Toni C, Dell'Osso L. General medical conditions in 347 bipolar disorder patients: clinical correlates of metabolic and autoimmune-allergic diseases. J Affect Disord 2015;170:95-103.

3. SayuriYamagata A, Brietzke E, Rosenblat JD, Kakar R, McIntyre RS. Medical comorbidity in bipolar disorder: The link with metabolic-inflammatory systems. J Affect Disord 2017;211:99-106.

4. Eaton WW, Pedersen MG, Nielsen PR, Mortensen PB. Autoimmune diseases, bipolar disorder, and non-affective psychosis. Bipolar Disord 2010;12:638-46.

5. Wang LY, Chiang JH, Chen SF, Shen YC. Systemic autoimmune diseases are associated with an increased risk of bipolar disorder: A nationwide population-based cohort study. J Affect Disord 2017;227:31-7.

6. Cremaschi L, Kardell M, Johansson V, Isgren A, Sellgren CM, Altamura AC, Hultman CM, Landén M.Prevalences of autoimmune diseases in schizophrenia, bipolar I and II disorder, and controls. Psychiatry Res 2017;258:9-14.

7. Barbuti M, Carvalho AF, Köhler CA, Murru A, Verdolini N, Guiso G, Samalin L, Maes M, Stubbs B, Perugi G, Vieta E, Pacchiarotti I. Thyroid autoimmunity in bipolar disorder: A systematic review. J Affect Disord 2017;221:97-106.

8. Tiosano S, Nir Z, Gendelman O, Comaneshter D, Amital H, Cohen AD, Amital D. The association between systemic lupus erythematosus and bipolar disorder - a big data analysis. Eur Psychiatry 2017;43:116-9.

9. Popescu A, H. Kao A. Neuropsychiatric Systemic Lupus Erythematosus. Curr Neuropharmacol 2011;9:449-57.

10. Spinosa MJ, Bandeira M, Liberalesso PB, Vieira SC, Janz LL Jr, Sá EG, Löhr A Jr. Clinical, laboratory and neuroimage findings in juvenile systemic lupus erythematosus presenting involvement of the nervous system. Arq Neuropsiquiatr 2007;65:433-9.

11. Marrie RA, Fisk JD, Tremlett H, Wolfson C, Warren S, Tennakoon A, Leung S, Patten SB; CIHR Team in the Epidemiology and Impact of Comorbidity on Multiple Sclerosis. Differences in the burden of psychiatric comorbidity in MS vs the general population. Neurology 2015;85:1972-9.

12. Murphy R, O'Donoghue S, Counihan T, McDonald C, Calabresi PA, Ahmed MA, Kaplin A, Hallahan B.Neuropsychiatric syndromes of multiple sclerosis. J Neurol Neurosurg Psychiatry 2017;88:697-708.

13. Kay-Lambkin FJ, Thornton L, Lappin JM, Hanstock T, Sylvia L, Jacka F, Baker AL, Berk M, Mitchell PB, Callister R, Rogers N, Webster S, Dennis S, Oldmeadow C, MacKinnon A, Doran C, Turner A, Hunt S Study protocol for a systematic review of evidence for lifestyle interventions targeting smoking, sleep, alcohol/other drug use, physical activity, and healthy diet in people with bipolar disorder. Syst Rev 2016;5:106.

14. Rosenblat JD, Mcintyre RS. Are medical comorbid conditions of bipolar disorder due to immune dysfunction? Acta Psychiatr Scand 2015;132:180-91.

15. Rege S, Hodgkinson SJ. Immune dysregulation and autoimmunity in bipolar disorder: Synthesis of the evidence and its clinical application. Aust New Zeal J Psychiatry 2013;47:1136-51.

16. Jun C, Choi Y, Lim SM, Bae S, Hong YS, Kim JE, Lyoo IK. Disturbance of the Glutamatergic System in Mood Disorders. Exp Neurobiol 2014;23:28.

17. Ohgi Y, Futamura T, Hashimoto K. Glutamate Signaling in Synaptogenesis and NMDA Receptors as Potential Therapeutic Targets for Psychiatric Disorders. Curr Mol Med 2015;15:20621.

18. Diazgranados N, Ibrahim L, Brutsche NE, Newberg A, Kronstein P, Khalife S, Kammerer WA, Quezado Z, Luckenbaugh DA, Salvadore G, Machado-Vieira R, Manji HK, Zarate CA Jr. A randomized add-on trial of an N-methyl-Daspartate antagonist in treatment-resistant bipolar depression. Arch Gen Psychiatry 2010;67:793-802.

19. Zarate CA Jr, Brutsche NE, Ibrahim L, Franco-Chaves J, Diazgranados N, Cravchik A, Selter J, Marquardt CA, Liberty $\mathrm{V}$, Luckenbaugh DA.Replication of ketamine's antidepressant efficacy in bipolar depression: A randomized controlled add-on trial. Biol Psychiatry 2012;71:939-46.

20. Petroff OAC. Book Review: GABA and Glutamate in the Human Brain. Neurosci 2002;8:562-73.

21. Cserép C, Szabadits E, Szonyi A, Watanabe M, Freund TF, Nyiri G. NMDA Receptors in GABAergic Synapses during Postnatal Development. PLoS One 2012; 7:e37753.

22. Cherlyn SYT, Woon PS, Liu JJ, Ong WY, Tsai GC, Sim K. Genetic association studies of glutamate, GABA and related genes in schizophrenia and bipolar disorder: A decade of advance. Neurosci Biobehav Rev 2010;34:958-77.

23. Fatemi SH, Folsom TD, Thuras PD. GABA A and GABA B receptor dysregulation in superior frontal cortex of subjects with schizophrenia and bipolar disorder. Synapse 2017;71:e21973.

24. Craddock N, Jones L, Jones IR, Kirov G, Green EK, Grozeva D, Moskvina V, Nikolov I, Hamshere ML, Vukcevic D, Caesar S, Gordon-Smith K, Fraser C, Russell E, Norton N, Breen G, St Clair D, Collier DA, Young AH, Ferrier IN, Farmer A, McGuffin P, Holmans PA; Wellcome Trust Case Control Consortium (WTCCC), Donnelly P, Owen MJ, O'Donovan MC. Strong genetic evidence for a selective influence of GABAA receptors on a component of the bipolar disorder phenotype. Mol Psychiatry 2010;15:146-53.

25. Maletic V, Raison C. Integrated neurobiology of bipolar disorder. Front Psychiatry 2014;5:98.

26. Korinek M, Kapras V, Vyklicky V, Adamusova E, Borovska J, Vales K, Stuchlik A, Horak M, Chodounska H, Vyklicky L Jr. Neurosteroid modulation of N-methyl-d-aspartate receptors: Molecular mechanism and behavioral effects. Steroids 
2011;76:1409-18.

27. Stephenson FA, Cousins SL, Kenny A V. Assembly and forward trafficking of NMDA receptors (Review). Mol Membr Biol 2008;25:311-20.

28. Vitaliani R, Mason W, Ances B, Zwerdling T, Jiang Z, Dalmau J. Paraneoplastic encephalitis, psychiatric symptoms, and hypoventilation in ovarian teratoma. Ann Neurol 2005;58:594-604.

29. Dalmau J, Tüzün E, Wu HY, Masjuan J, Rossi JE, Voloschin A, Baehring JM, Shimazaki H, Koide R, King D, Mason W, Sansing LH, Dichter MA, Rosenfeld MR, Lynch DR.Paraneoplastic anti-N-methyl-D-aspartate receptor encephalitis associated with ovarian teratoma. Ann Neurol 2007; $61: 25-36$

30. Dalmau J, Lancaster E, Martinez-Hernandez E, Rosenfeld MR, Balice-Gordon R. Clinical experience and laboratory investigations in patients with anti-NMDAR encephalitis. Lancet Neurol 2011;10:63-74.

31. Venkatesan A, Adatia K. Anti-NMDA-Receptor Encephalitis: From Bench to Clinic. ACS Chem Neurosci 2017;8:2586-95.

32. Hughes EG, Peng X, Gleichman AJ, Lai M, Zhou L, Tsou R, Parsons TD, Lynch DR, Dalmau J, Balice-Gordon RJ. Cellular and synaptic mechanisms of anti-NMDA receptor encephalitis. J Neurosci 2010;30:5866-75.

33. Pollak TA, McCormack R, Peakman M, Nicholson TR, David AS. Prevalence of anti-N-methyl-d-aspartate (NMDA) receptor antibodies in patients with schizophrenia and related psychoses: a systematic review and meta-analysis. Psychol Med 2014;44:2475-87.

34. Pollak TA, Beck K, Irani SR, Howes OD, David AS, McGuire PK. Autoantibodies to central nervous system neuronal surface antigens: psychiatric symptoms and psychopharmacological implications. Psychopharmacology (Berl) 2016;233:1605-21.

35. León-Caballero J, Pacchiarotti I, Murru A, Valentí M, Colom F, Benach B, Pérez V, Dalmau J, Vieta E.Bipolar disorder and antibodies against the N-methyl-d-aspartate receptor: A gate to the involvement of autoimmunity in the pathophysiology of bipolar illness. Neurosci Biobehav Rev 2015;55:403-12.

36. Dickerson F, Stallings C, Vaughan C, Origoni A, Khushalani $\mathrm{S}$, Yolken R. Antibodies to the glutamate receptor in mania. Bipolar Disord 2012;14:547-53.

37. Lennox BR, Palmer-Cooper EC, Pollak T, Hainsworth J, Marks J, Jacobson L, Lang B, Fox H, Ferry B, Scoriels L, Crowley H, Jones PB, Harrison PJ, Vincent A; PPiP study team. Prevalence and clinical characteristics of serum neuronal cell surface antibodies in first-episode psychosis: a case-control study. The Lancet Psychiatry 2017;4:42-8.

38. Steiner J, Walter M, Glanz W, Sarnyai Z, Bernstein HG, Vielhaber S, Kästner A, Skalej M, Jordan W, Schiltz K, Klingbeil $\mathrm{C}$, Wandinger KP, Bogerts B, Stoecker W. Increased prevalence of diverse N-methyl-D-aspartate glutamate receptor antibodies in patients with an initial diagnosis of schizophrenia: Specific relevance of $\mathrm{IgG} \mathrm{NR} 1 \mathrm{a}$ antibodies for distinction from $\mathrm{N}$ methyl-D-aspartate glutamate receptor encephalitis. JAMA Psychiatry 2013;70:271-8.
39. Hammer C, Stepniak B, Schneider A, Papiol S, Tantra M, Begemann M, Sirén AL, Pardo LA, Sperling S, Mohd Jofrry S, Gurvich A, Jensen N, Ostmeier K, Lühder F, Probst C, Martens H, Gillis M, Saher G, Assogna F, Spalletta G, Stöcker W, Schulz TF, Nave KA, Ehrenreich HNeuropsychiatric disease relevance of circulating anti-NMDA receptor autoantibodies depends on blood-brain barrier integrity. Mol Psychiatry 2014;19:1143-9.

40. Pearlman DM, Najjar S. Meta-analysis of the association between $\mathrm{N}$-methyl-d-aspartate receptor antibodies and schizophrenia, schizoaffective disorder, bipolar disorder, and major depressive disorder. Schizophr Res 2014;157:249-58.

41. Ngo ST, Steyn FJ, McCombe PA. Gender differences in autoimmune disease. Front Neuroendocrinol 2014;35:347-69.

42. Fairweather D, Frisancho-Kiss S, Rose NR. Sex differences in autoimmune disease from a pathological perspective. Am J Pathol 2008;173:600-9.

43. Eaton WW, Pedersen MG, Nielsen PR, Mortensen PB. Autoimmune diseases, bipolar disorder, and non-affective psychosis. Bipolar Disord 2010;12:638-46.

44. Rainville JR, Tsyglakova M, Hodes GE. Deciphering sex differences in the immune system and depression. Front Neuroendocrinol 2018. doi:10.1016/j.yfrne.2017.12.004.

45. Özerdem A, Rasgon N. Women with bipolar disorder: A lifetime challenge from diagnosis to treatment. Bipolar Disord 2014;16:1-4.

46. Scott J, Brichant-Petitjean C, Etain B, Henry C, Kahn JP, Azorin JM, Leboyer M, Bellivier F. A re-examination of antidepressant treatment-emergent mania in bipolar disorders: evidence of gender differences. Acta Psychiatr Scand 2017;135:47988 .

47. Diflorio A, Jones I. Is sex important Gender differences in bipolar disorder. Int Rev Psychiatry 2010;22:437-52.

48. Fellinger M, Waldhoer T, König D, Hinterbuchinger B, Pruckner N, Baumgartner J, Vyssoki S, Vyssoki B. Seasonality in bipolar disorder: Effect of sex and age. J Affect Disord. 2019; 15;243:322-326.

49. Baskaran A, Cha DS, Powell AM, Jalil D, Mcintyre RS. Sex differences in rates of obesity in bipolar disorder: Postulated mechanisms. Bipolar Disord 2014;16:83-92.

50. Cobo J, Giménez-Palop O, Patró E, Pérez M, Bleda F, Barbero JD, Oliva JC, Serrano R, Berlanga E, García-Parés G, Palao D. Lack of confirmation of thyroid endophenotype in Bipolar Disorder Type I and their first-degree relatives. Psychoneuroendocrinology 2015;51:351-64.

51. Vonk R, van der Schot AC, Kahn RS, Nolen WA, Drexhage HA. Is Autoimmune Thyroiditis Part of the Genetic Vulnerability (or an Endophenotype) for Bipolar Disorder? Biol Psychiatry 2007;62:135-40.

52. Bauer M, Glenn T, Pilhatsch M, Pfennig A, Whybrow PC. Gender differences in thyroid system function: Relevance to bipolar disorder and its treatment. Bipolar Disord 2014;16:5871.

53. Özerdem A, Tunca Z, Çımrın D, Hıdıroğlu C, Ergör G. Female vulnerability for thyroid function abnormality in bipolar disorder: role of lithium treatment. Bipolar Disord 2014;16:7282 . 
54. Breslau N, Merikangas K, Bowden CL. Comorbidity of migraine and major affective disorders. Neurology 1994;44:S1722.

55. Saunders EF, Nazir R, Kamali M, Ryan KA, Evans S, Langenecker S, Gelenberg AJ, McInnis MG. Gender differences, clinical correlates, and longitudinal outcome of bipolar disorder with comorbid migraine. J Clin Psychiatry 2014;75:5129.

56. Ceylan D, Scola G, Tunca Z, Isaacs-Trepanier C, Can G, Andreazza AC, Young LT, Özerdem A. DNA redox modulations and global DNA methylation in bipolar disorder: Effects of sex, smoking and illness state. Psychiatry Res 2018;261.

57. Sanchez-Autet M, Arranz B, Safont G, Sierra P, GarciaBlanco A, de la Fuente L, Garriga M, García-Portilla MP. Gender differences in C-reactive protein and homocysteine modulation of cognitive performance and real-world functioning in bipolar disorder. J Affect Disord 2018;229:95-104.

58. Suwalska A, Lojko D. Sex dependence of cognitive functions in bipolar disorder. Sci World J 2014;2014:1-10.

59. Shi J, Guo H, Fan F, Fan H, An H, Wang Z, Tan S, Yang F, Tan Y. Sex differences of hippocampal structure in bipolar disorder. Psychiatry Res - Neuroimaging 2018;273:35-41.

60. Jogia J, Dima D, Frangou S. Sex differences in bipolar disorder: A review of neuroimaging findings and new evidence. Bipolar Disord 2012;14:461-71.

61. Wang LY, Chiang JH, Chen SF, Shen YC. Systemic autoimmune diseases are associated with an increased risk of bipolar disorder: A nationwide population-based cohort study. J Affect Disord 2017;227:31-7.

62. First MB, Spitzer RL, Gibbon M, Williams JBW. Structured Clinical Interview for DSM-IV Axis I Disorders, Clinician Version (SCID-CV). 2009.

63. Karadağ F, Oral ET, Yalçın Aran F, Erten E. Young mani derecelendirme ölçeğinin Türkiye'de geçerlik ve güvenilirliği. Türk Psikiyatri Dergisi, 2001; 13, 107-114.

64. Akdemir A, Dağ İ, Türkçapar H, İşcan N, Özbay H. Hamilton Depresyon Derecelendirme Ölçeği (HDDÖ)'nin geçerliği, güvenilirliği ve klinikte kullanımı. Psikiyatri Psikoloji Psikofarmakoloji Dergisi, 1996; 4(4), 251-59.

65. Bussner J, Targum SD. The clinical global impressions scale: applying a research tool in clinical practice, Psychiatry (Edgmont) 4 2007; 28-37.

66. Patterson DA, Lee MS. Field trial of the global assessment of functioning scalemodified. Am. J. Psychiatry. 1995; 152: 13861388.

67. Kupka RW, Nolen WA, Post RM, McElroy SL, Altshuler LL, Denicoff KD, Frye MA, Keck PE Jr, Leverich GS, Rush AJ, Suppes T, Pollio C, Drexhage HA. High rate of autoimmune thyroiditis in bipolar disorder: lack of association with lithium exposure. Biol Psychiatry 2002;51:305-11.

68. Padmos RC, Bekris L, Knijff EM, Tiemeier H, Kupka RW, Cohen D, Nolen WA, Lernmark A, Drexhage HA.A high prevalence of organ-specific autoimmunity in patients with bipolar disorder. Biol Psychiatry 2004;56:476-82.

69. Bocchetta A, Traccis F, Mosca E, Serra A, Tamburini G,
Loviselli A. Bipolar disorder and antithyroid antibodies: review and case series. Int J Bipolar Disord 2016;4:5.

70. Severance EG, Gressitt KL, Yang S, Stallings CR, Origoni AE, Vaughan C, Khushalani S, Alaedini A, Dickerson FB, Yolken RH. Seroreactive marker for inflammatory bowel disease and associations with antibodies to dietary proteins in bipolar disorder. Bipolar Disord 2014;16:230-40.

71. Dickerson F, Stallings C, Origoni A, Katsafanas E, Schweinfurth L, Savage C, Khushalani S, Yolken R. Antibodies to Toxoplasma gondii and cognitive functioning in schizophrenia, bipolar disorder, and nonpsychiatric controls. J Nerv Ment Dis 2014;202:589-93.

72. Gonzalez-Quintela A, Alende R, Gude F, Campos J, Rey J, Meijide LM, Fernandez-Merino C, Vidal C. Serum levels of immunoglobulins (IgG, IgA, IgM) in a general adult population and their relationship with alcohol consumption, smoking and common metabolic abnormalities. Clin Exp Immunol 2008;151:42-50.

73. Maddison SE, Reimer CB. Normative values of serum immunoglobulins by single radial immunodiffusion: a review. Clin Chem 1976;22:594-601.

74. Lennox BR, Palmer-Cooper EC, Pollak T, Hainsworth J, Marks J, Jacobson L, Lang B, Fox H, Ferry B, Scoriels L, Crowley H, Jones PB, Harrison PJ, Vincent A; PPiP study team. Prevalence and clinical characteristics of serum neuronal cell surface antibodies in first-episode psychosis: a case-control study. The Lancet Psychiatry 2017;4:42-8.

75. Choe CU, Karamatskos E, Schattling B, Leypoldt F, Liuzzi G, Gerloff C, Friese MA, Mulert C. A clinical and neurobiological case of IgM NMDA receptor antibody associated encephalitis mimicking bipolar disorder. Psychiatry Res 2013;208:194-6.

76. Kuo YL, Tsai HF, Lai MC, Lin CH, Yang YK. Anti-NMDA receptor encephalitis with the initial presentation of psychotic mania. J Clin Neurosci 2012;19:896-8

77. Parratt KL, Allan M, Lewis SJG, Dalmau J, Halmagyi GM, Spies JM. Acute psychiatric illness in a young woman: an unusual form of encephalitis. Med J Aust 2009;191:284-6.

78. Simabukuro MM, Freitas CH de A, Castro LHM. A patient with a long history of relapsing psychosis and mania presenting with anti-NMDA receptor encephalitis ten years after first episode. Dement Neuropsychol 2015;9:311-4.

79. Lapteva L, Nowak M, Yarboro CH, Takada K, RoebuckSpencer T, Weickert T, Bleiberg J, Rosenstein D, Pao M, Patronas N, Steele S, Manzano M, van der Veen JW, Lipsky PE, Marenco S, Wesley R, Volpe B, Diamond B, Illei GG Anti-Nmethyl-D-aspartate receptor antibodies, cognitive dysfunction, and depression in systemic lupus erythematosus. Arthritis Rheum 2006;54:2505-14.

80. Rybakowski JK. Antiviral and immunomodulatory effect of lithium. Pharmacopsychiatry 2000;33:159-64.

81. Nassar A, Azab AN. Effects of lithium on inflammation. ACS Chem Neurosci 2014;5:451-8.

82. Ozerdem A, Ceylan D, Targitay B. The relationship between Lithium and cancer proliferation: A case-based review of the literature. Curr Drug Metab 2018;19.

83. Hashimoto R, Hough C, Nakazawa T, Yamamoto T, Chuang 
DM. Lithium protection against glutamate excitotoxicity in rat cerebral cortical neurons: Involvement of NMDA receptor inhibition possibly by decreasing NR2B tyrosine phosphorylation. J Neurochem 2002;80:589-97.

84. Nonaka S, Hough CJ, Chuang DM. Chronic lithium treatment robustly protects neurons in the central nervous system against excitotoxicity by inhibiting N-methyl-D-aspartate receptor-mediated calcium influx. Proc Natl Acad Sci 1998;95:2642-7.

85. Du J, Quiroz J, Yuan P, Zarate C, Manji HK. Bipolar disorder: involvement of signaling cascades and AMPA receptor trafficking at synapses. Neuron Glia Biol 2004;1:231-43.

86. Kaneez FS, Saeed SA. Investigating GABA and its function in platelets as compared to neurons. Platelets 2009;20:328-33.

87. Borges VC, Nogueira CW, Zeni G, Rocha JBT. Organochalcogens affect the glutamatergic neurotransmission in human platelets. Neurochem Res 2004;29:1505-9.

88. Franconi F, Miceli M, De Montis MG, Crisafi EL, Bennardini F, Tagliamonte A. NMDA receptors play an antiaggregating role in human platelets. Thromb Haemost 1996;76:84-7.

89. Hitchcock IS, Skerry TM, Howard MR, Genever PG. NMDA receptor-mediated regulation of human megakaryocytopoiesis. Blood 2003;102:1254-9.

90. Kalev-Zylinska ML, Green TN, Morel-Kopp MC, Sun PP, Park YE, Lasham A, During MJ, Ward CM. N-methyl-d-aspartate receptors amplify activation and aggregation of human platelets. Thromb Res 2014;133:837-47.

91. Baier PC, Koch JM, Seeck-Hirschner M, Ohlmeyer K, Wilms S, Aldenhoff JB, Hinze-Selch D. A flow-cytometric method to investigate glutamate-receptor-sensitivity in whole blood platelets - Results from healthy controls and patients with schizophrenia. J Psychiatr Res 2009;43:585-91.

92. Berk M, Plein H, Csizmadia T. Supersensitive platelet glutamate receptors as a possible peripheral marker in schizophrenia. Int Clin Psychopharmacol 1999;14:119-22.

93. Berk M, Plein H, Ferreira D. Platelet glutamate receptor supersensitivity in major depressive disorder. Clin Neuropharmacol 2001;24:129-32.

94. Do Nascimento CAM, Nogueira CW, Borges VC, Rocha JBT. Changes in $(3 \mathrm{H})$-glutamate uptake into platelets from patients with bipolar I disorder. Psychiatry Res 2006;141:343-7.

95. Myung JK, Dunah AW, Yu TW, Sheng M. Differential roles of NR2A- and NR2B-containing NMDA receptors in Ras-ERK signaling and AMPA receptor trafficking. Neuron 2005;46:74560 .

96. Park HJ, Kang WS, Paik JW, Kim JW. Effect of valproic acid through regulation of NMDA receptor-ERK signaling in sleep deprivation rats. J Mol Neurosci 2012;47:554-8.

97. McDermott CM, Hardy MN, Bazan NG, Magee JC. Sleep deprivation-induced alterations in excitatory synaptic transmission in the CA1 region of the rat hippocampus. J Physiol 2006;570:553-65.

98. Ramadan E, Basselin M, Rao JS, Chang L, Chen M, Ma K, Rapoport SI. Lamotrigine blocks NMDA receptor-initiated arachidonic acid signalling in rat brain: implications for its effi- cacy in bipolar disorder. Int $\mathbf{J}$ Neuropsychopharmacol 2012;15:931-43.

99. Sourial-Bassillious N, Rydelius PA, Aperia A, Aizman O. Glutamate-mediated calcium signaling: A potential target for lithium action. Neuroscience 2009;161:1126-34.

100. Jacoby AS, Munkholm K, Vinberg M, Pedersen BK, Kessing LV. Cytokines, brain-derived neurotrophic factor and Creactive protein in bipolar i disorder - Results from a prospective study. J Affect Disord 2016;197.

101. Ghasemi M, Phillips C, Trillo L, De Miguel Z, Das D, Salehi A. The role of NMDA receptors in the pathophysiology and treatment of mood disorders. Neurosci Biobehav Rev 2014;47:336-58.

102. Zink M, Englisch S, Schmitt A. Antipsychotic treatment modulates glutamate transport and NMDA receptor expression. Eur Arch Psychiatry Clin Neurosci 2014;264:67-82.

103. Huang YY, Liu YC, Lee CT, Lin YC, Wang ML, Yang YP, Chang KY, Chiou SH. Revisiting the lamotrigine-mediated effect on hippocampal GABAergic transmission. Int J Mol Sci 2016;17.

104. Motohashi N. GABA receptor alterations after chronic lithium administration. Comparison with carbamazepine and sodium valproate. Prog Neuropsychopharmacol Biol Psychiatry 1992;16:571-9.

105. Pehrson AL, Sanchez C. Altered ?-aminobutyric acid neurotransmission in major depressive disorder: A critical review of the supporting evidence and the influence of serotonergic antidepressants. Drug Des Devel Ther 2015;9:603-24.

106. Silver HB, Einoch RB, Youdim M, Weinreb OB. The role of gaba-A receptor in the synergism between SSRI and antipsychotic in schizophrenia; implications for antipsychotic modes of actions. Curr Med Chem 2013;20:363-70. 